\title{
PEMBERITAAN MEDIA ONLINE: STUDI KASUS KONFLIK BUDAYA "SEDEKAH LAUT" DI PANTAI BARU, NGENTAK, BANTUL, YOGYAKARTA
}

\author{
Eko Saputra ${ }^{1^{*}}$, Iswandi Syahputra ${ }^{1}$, Bono Setyo $^{1}$ \\ ${ }^{1}$ UIN Sunan Kalijaga Yogyakarta, Indonesia \\ *e-mail: eko322590@gmail.com
}

\begin{abstract}
Abstrak
Penelitian ini menelisik tentang konflik Sedekah Laut melalui media online di Pantai Baru, Dusun Ngentak, Desa Poncosari, Bantul-Yogyakarta. Berangkat dari fenomena sosial. Artikel ini membahas mengenai bagaimana media online melaporkan peristiwa konflik Sedekah Laut di Pantai Baru, bagaimana media online memposisisikan pemberitaanya terhadap kepentingan publik dan institusi medianya dan bagaimana media online membentuk fakta dan opini publik di masyarakat. Studi ini menggunakan metode kualitaif dengan pendekatan analisis isi kualitatif (qualitatif massage analisis). Hasil studi ini menunjukan bahwa konflik Sedekah Laut di Pantai Baru disebabkan oleh perbedaan interpretasi hukum Islam dalam memahami Sedekah Laut. Kelompok konservatif menilai, tidakan tradisi Sekekah laut ialah menyimpang dari Islam, dengan kata lain haram, syirik (yang dapat menyebabkan seorang bisa keluar dari Islam). Sementara kelompok Islam moderat dan respon masyarakat setempat, sedah laut tidak menyimpang dari nilai ajaran Islam. Justru dengan kehadiran tradisi tersebut, membuat masyarakat semakin religious, memperkuat keimananya dan menguatkan hubungan persaudaraan.
\end{abstract}

Kata Kunci: Pemberitaan Media Online; Konflik; Sedekah Laut

\section{Abstract}

The research examines the online media Sedekah Laut's conflict, the village of Ngentak, Poncosari, and Bantul-Yogyakarta. This article will discuss how the online media reported the Sedekah Laut's conflict at Pantai Baru, how does the online media position its reporting on the interests of the public and its media institutions, and how do online media shape public opinion and fact in people. The study involves a qualitative (qualitative-quantitative analysis). The results of this study indicate that different interpretations of Islamic law cause the conflict Sedekah Laut's in Pantai Baru's in understanding "Sedekah Laut". Conservative groups consider that the act of the Sedekah Laut tradition is deviating from Islam. In other words, haram, shirk (which can cause a person to leave Islam). While moderate Islamic groups and the local community's response, the Sedekah Laut does not deviate from Islamic teachings' values. By the presence of these Sedekah Laut's traditions, Precisely makes the community more religious, strengthens its faith, and strengthens brotherhood.

Keywords: Online Media Reporting; Conflict; Sedekah Laut's

\section{PENDAHULUAN}

Sedekah Laut telah menjadi tradisi rutinitas masarakat pesisir Jawa dalam setiap tahunnya. Tradisi ini secara turun temurun diwarisakan oleh nenek moyang mereka (Riska, 2018). Di tahun sebelumnya, tradisi Sedekah Laut di masyarakat Jawa pesisir berjalan dengan baik tanpa adanya konflik. Namun, belakangan ini pelaksanaan tradisi tersebut menimbulkan konflik sosial di tengah masyarakat Pantai Baru, Ngentak. Konflik ini disebabkan oleh perbedaan pandangan tentang hukum Sedekah Laut.
Bagi kelompom Islam Salafi tradisi tersebut haram hukumnya untuk dilakukan. Sedangkan masyarakat Pantai Baru bersikap sebaliknya. Sejalan dengan masyarakat setempat, kelompok Islam moderat juga bersebrangan dengan kelompok Salafi yang mengharamkan tradisi tersebut.

Sehari sebelum acara Sedekah Laut dilaksanakan, datang sekelompok orang tidak dikenal merusak properti acara Sedekah Laut. Selain itu, mereka juga mengecam ke masyarakat setempat bahwa acara tersebut tidak boleh dilakukan 
kembali. Pada akhirnya perusakan dan kecaman ysng dilakukan oleh kelompok Salafi ini menimbulkan konflik di tengah masyarakat Ngentak (Kompas.com 25/12/2018).

Dalam konteks culture of histories, prilaku manusia yang membentuk budaya sudah ada sejak manusia itu berada dalam kandungan, di mana anak mencatat dari segala aktivitas yang dilakukan oleh orang tuanya dalam kehidupan sehari-hari. Proses intekrasi antara seorang anak dan orang tua dalam kandungan menghasilkan benih kebiasaan pada seorang anak.

Kebiasaan tersebut akan terus berlanjut ketika ia tumbuh besar bersama dengan lingkungannya. Melalui lingkungan keluarga dan masyarakat, seorang anak akan membentuk kebiasaan berdasarkan apa yang ia lihat. Dalam kontek ini, lingkungan sangat mempengaruhi karakter dari seorang anak. Ketika kebiasaan itu dilakukan secara berulang-ulang maka di sanalah budaya itu terbentuk. Seperti itulah budaya itu bekerja secara alami dalam siklus kehidupan umat manusia.

Menurut Abdurrohman

kebudayaan merupakan hasil karya, rasa dan cipta masyarakat yang menghasilkan berupa kebudayaan kebendaan yang tertanam dalam bentuk kaidah dan nilai-nilai moral yang mengikat.

Secara historis, Indonesia diapit oleh beragam pulau, memiliki bermacam suku budaya dan bahasa. Keberagaman ini yang membuat Indonesia semakin indah. Dari keragaman tersebut memiliki karakteristik nilai yang berbeda-beda. Di satu sisi budaya juga dapat diartikan sebagai jaringan kerja yang sudah tertanam di dalam pikiran manusia dimulai dari kehidupan awal mula eksistensi manusia ada (Sumanjuntak, Sarawati dan Sukirno, 2019).

Di Indonesia, meyakini terhadap nilai tertentu (kepercayaan, tradisi dan budaya) adalah bagian dari kehidupan masyarakat Indonesia yang tidak dapat dilepaskan dari kehidupan sehari-hari. Karena budaya lokal sebagai penanda identitas. Dalam konten seperti ini, budaya tidak dapat dilepaskan dari kepercayaan, agama, bahasa, suku dan adat-istadat. Terutama masyarakat pesisir yang kental dengan budaya melautnya, atau Meraungnya (ritual upacara laut). Lebih lanjut, Simanjuntak, Sarawati dan Sukirno (2019) mengatakan perayaan seperti upacara Sedekah Laut tidak hanya sebatas ritual sakral, tetapi sudah menjadi bagaian dari fungsi ekonomi, komunikasi, dan hiburan masyarakat pesisir. Di samping itu, Sedekah Laut juga mempunyai peranan penting dalam pendidikan masyarakat. Di antaranya untuk melestarikan nilai-nilai ajaran leluhur, spiritual, etos kerja, pelestarian budaya dan alam (Widati, 2011).

Menelisik kehidupan umat Islam di nusantara tidak terlepas pengaruhnya dari budaya lokal yang menunjukan identitas khusus Muslim di Indonesia. Tentu budaya akan mempengaruhi penyebaran agama Islam di Indonesia. Seperti yang dilakukan oleh Wali Songo (Wali Sembilan) terhadulu yang mengambil unsur buday lokal sebagai metode dakwahnya. Dari budayalah ajaran yang dibawa oleh Wali Songo di terima oleh masyarakat pribumi. Budaya lokal yang menyatu dengan Islam sampai saat ini terus masih berlangsung. Bahkan dalam praktiknya, masayarakat Jawa masih kental dengan nuansa budaya lokalnya (mistis) yang sudah tertanam sejak lama sebelum Islam masuk ke Indonesia. Khusunya umat Islam dari kalngan orang Abangan.

Islam yang tertanam dalam nilainilai lokal sampai saat ini masih eksis. Islam Abangan di Indonesia dinamai sebagai Islam "yang kental dengan tradisi budaya Jawa". Praktik kesehariannya Islam Abangan tidak bisa terlepas dari 'singkretisme' - Islam yang dilabeli dengan 'mistis' (kepercayaan terhadap tertentu), aniesme (roh halus) dan 'Hinduisme' (terbawa pengaruh agama sebelumnya).

Menurut Geertz (2013) Islam Jawa diidentifikasi sebagai Islam Nusantara yang memiliki karakteristik unik, mistis, anemis, singkretis dan lain-lain. Kearifan nilai lokal yang tertanam pada masyarakat Islam Abangan menjadi membeda dari identitas kelompok Islam yang lain, bahkan di luar negara lain.

Geertz mengatakan Secara umum Geertz mengkelompokkan Islam Jawa menjadi tiga bagian, yaitu 'Priyayi', 'Santri' dan 'Abangan'. Perbedaan antara Islam Priyai, Santri dan Abangan terletak dari konsep ajarannya. Islam Priyayi dan santri ialah kelompok Islam yang menjalankan ajaran Islam secara murni sesuai dengan syariat Islam. Sedangkan Islam Abangan sebaliknya - kelompok Islam yang tidak terlepas dari praktik ritual budaya Jawa.

Geertz dalam pandangannya mengenai tradisi Jawa ia mengatakan perayaan tradisi Jawa secara turun temurun sudah menjadi bagian dari rutinitas siklus kehidupan masyarakat Jawa. Tradisi tersebut menjadi bagian dari ruh kehidupan 
masyarakat Islam Jawa. Perayaan seperti ini selalu mendapatkan apresasi di tengah masyarakat setempat. Karena berhubungan dengan rasa syukur dan hari kemenangan.

$$
\text { Rosyit (2015) mengatakan }
$$

"toleransi" adalah alat utama untuk menyatukan masyarakat. Toleransi memiliki nilai sikap untuk menghargai antar sesama dalam kehidupan sosial. Namun, belakangan ini nilai tolenasi menjadi hilang karena disebabkan oleh kehadiran kelompok konserfatif atau fundamentalis yang mengembalikan budaya dalam makna aslinyanya. Dalam tradisi lain (seperti Sedekah Laut) belakangan ini mendapatkan penolakan dari sejumlah pihak.

Di tahun 2018 silam, tradisi ini menuai penolakan dari sejumlah kelompok yang mengatasnamakan Islam. penolakan tersebut berujung pada tindakan konflik sosial di tengah masyarakat. Seperti yang terjadi di dusun Gantek, desa Pantai Baru, Bantul Yogyakarta. Berdasarkan berita media Kompas.com sekelompok orang yang mengatasnamakan Islam datang ke tempat acara pelaksanaan Sedekah Laut sehari sebelum acara dilaksanakan. Mereka merusak properti Sedekah Laut. Perusakan ini dengan alasan bahwa tradisi tersebut menyimpang dari nilai ajaran Islam.

Kemudian, dalam sebuah laporan media online, Nu.co.id memberitakan topik yang sama. Dalam rubik tersebut dikatakan "dari arah yang tidak dikenal, datang sekelompok orang mengatasnamakan Islam merusak properti Sedekah Laut' (Nu.or.id 25/12/2018; Kompas.com 25/12/2018).

Sepotong kalimat ini menjelaskan tentang terjadinya peristiwa kerusakan properti Sedekah Laut yang disebabkan oleh sekelompok orang yang tidak dikenal. Berita ini dikonfirmasi oleh media Kompas.com yang mengatakan:

"Sehari sebelum acara dilakukan, sekelompok orang yang tidak dikenal merusak segala bentuk atribut Sedekah Laut. Mulai dari tenda, kursi, Labuhan, Pangkur sampai Gambyong. Hanya saja tinggal satu yang tersisa, yaitu Reog".

Media Kompas.com membenarkan terjadinya tindakan perusakan properti Sedekah Laut oleh sekelompok orang yang tidak dikenal. Sekelompok tersebut telah merusak persiapan acara perayaan tradisi masyarakat pantai Pesisir. Mereka merusak berbagai atribut yang dijadikan sebagai ritual acara Sedekah Laut. Tidak lama kemudian media lain ikut memberitakan konflik Sedekah Laut tersebut. Seperti media

Harianjogja.com, Tribunjogja.com,Detik.com ,Liputan6.com, dan swaramerdeka.com.

Melalui berbagai pemberitaan di atas, selama dua minggu terakhir berita tersebut menjadi perbincangan hangat di tengah masyarakat Jawa, khususnya Yogyakarta. Masyarakat Jawa mulai geram atas tindakan yang dilakukan oleh seorang kelompok yang mengatasnamakan agama datang, kemudian kelompok tersebut merusak properti Sedekah Laut di Pantai Baru.

Melalui pristiwa tersebut, masyarakat banyak menaruk simpati kepada masyarakat Pantai Baru Ngentak. Seperti Nuril misalnya, ia mengatakan bahwa Sedekah Laut ia anggap tidak bertentangan dengan nilai Islam. Nuril menegaskan bahwa "Sedekah Laut jangan hanya dilihat dari luarnya saja, akan tetapi isinya juga?'. Lebih lanjut, Nuril menambahkan "Sedekah Laut merupakan produk dari penyatuan nilai-nilai lokal dengan Islam. Jadi tidak perlu dipersoalkan"(Jogjaharian.com

26/12/2018).

Berdasarkan kutipan yang disampaikan oleh Nuril, seharusnya tindakan main hakim sendiri tidak seharusnya dilakukan. Karena hal ini menyangkut tentang nilai kearifan lokal dan bagaimana Islam menyatu dalam masyarakat lokal. Hal ini sejalan dengan pendapat yang disampaikan oleh Simanjuntak, Surawati dan Sukirno (2019). Sedekah Laut adalah warisan kebudayaaan turun temurun dari nenek moyang yang untuk melindungi masyarakat nelayan untuk terhindari dari mara bahaya dalam aktivitas melaut. Lebih lanjut ia mengatakan Sedekah Laut sebagai bentuk dari rasa syukur masyarakat nelayan atas keselamatan dan penghasilan yang melimpah.

Menurut pendapat J. Powel dalam studinya mengenai budaya, budaya yang tertanam secara mengakar di dalam masyarkat adalah tradisi yang memilki nilai yang mendalam secara turun temurun. Tradisi yang tertanam secara lokal bisanya terjadinya peleburan antara budaya lokal dengan budaya asing. Kedua budaya ini bertemu dan kemudian mengalami penyatuan, pada akhirnya menghasilkan budaya baru. Dari berbagai kasus Dalam komunikasi antarbudaya, istilah ini disebut sebagai alkuturasi budaya (Astuti 2014). Budiono (2000) mengatakan bahwa manusia akan merespon budaya-budaya 
yang masuk dari luar untuk dipelajari, dipahami dan dipraktekkan. Dengan demikian, dapat dipahami bahwa manusia adalah makhluk budaya yang membentuk tingkah laku yang menghasilkan budaya (Astuti, 2014).

Studi-studi sebelumnya mengenai Dari konflik sosial-budaya Sedekah Laut telah banyak dibahas oleh para sarjana. Seperti Kusmintayu (2014), Solihah (2015), Badruzzaman (2016), Adha (2012), Wildan (2015), Rustiana dan Khotimah (2017) dan Ruslan (2014). Kusmintayu (2014) membahas tentang "Tradisi Sedekah Laut di Kabupaten Cilacap: Tinjauan Makna Kearifan Lokal, dan Relevansinya dengan Pembelajaran Bahasa Indonesia." Hasil setudinya menjelaskan bahwa tradisi Sedekah Laut memiliki relevansi dengan anak sekolah SMA dan SMK. Melalui mata pelajaran budaya, Sedekah Laut dijadikan sebagai nilai-nilai lokal untuk membangun karakter cinta budaya pada anak sekolah SMA dan SMK. Nilai-nilai lokal yang diajarkan diantaranya adalah tentang makna Sedekah Laut: religi, budaya, ekonomi, dan pendidikan.

Selanjutnya, studi Solihin membahas tentang pelaksanaan tradisi Rokat Tas'e Kecamatan Bangkalan Jawa Timur. Hasil setudinya menjelaskan bahwa tradisi Rokat Tas'e mengalami perubahan budaya. Semulanya tradisi Rokat Tas'e bernuansa animisme-dinamisme, sekarang bergeser ke Islami. Hal ini disebabkan oleh menguatnya nilai-nilai Islam di desa Gebang, Bangkalan. Seperti adanya muatan bacaan Tahlil, bacaan Shalawat, dan pembacaan doa kepada Allah SWT dalam pelaksanaan tradisi Rokat Tas'e. Kemudian studi lain yang dilakukan oleh Wildan (2015) membahas tentang etika ekologi Jawa dalam Sedekah Laut.

Berbeda dengan Wildan, Rustiana dan Khotimah (2017) membahas tentang Sedekah Laut dan Bumi sebagai pengaplikasian multikulturalisme beragama. Hasil studi Rustiana dan Khotimah (2017) mengatakan Sedekah Laut dan Bumi sebagai bentuk solidaritas yang tinggi untuk saling bergotong royong. Di samping itu, sebagai bentuk intropeksi diri, toleransi beragama dan rasa syukur kepada tuhan Yang Maha Kuasa. Sedangkan Ruslan (2014) dan Kosmintayu (2014) menelisik tentang sepirit ritual Sedekah Laut masyarakat pesisir Kangkung, Bumi Waras. Penelitiannya menunjukan bahwa ritual Sedekah Laut sebagai ekspresi religius masyarakat Kangkung atas ungkapan rasa syukur mereka kepada tuhan Yang Maha Esa.

Dari berbagai studi-studi literatur yang ada. Para sarjana menempatkan ritual Sedekah Laut dalam konteks offline. Sedangkan online belum banyak dilakukan. Hal ini menujukan bahwa perhatian para sarjana tentang studi Sedekah Laut di media online terabaikan. Padahal, di era digital ini, keberadaan media online sangat penting dalam menyampaikan informasi ke publik. Melalui internet, publik dapat mengetahui segala pristiwa yang terjadi di masyarakat lain. Di samping itu, masyarakat juga dapat merespon pristiwa-pristiwa sosial dan budaya melalui pemberitaan media online. Oleh sebab itu, pada artikel ini penulis akan mengkaji konflik budaya tradisi Sedekah Laut melalui media online di Pantai Baru.

Berpijak dari problematisasi akademik tersebut, pentingnya penulis untuk mengkaji Sedekah Laut dalam rubik media online (lokal maupun nasional). Melalui penelitian ini, studi ini berkontribusi pada teori akademik dengan mengambil studi kasus konflik budaya Sedekah Laut di ruang online. Penelitian ini dipandang masih baru, dan belum banyak dilakukan oleh para sarjana. Studi ini penting untuk dilakukan, karena penulis ingin melihat bagaimana peranan, keterlibatan dan kecenderungan media online saat memberitakan peristiwa konflik budaya Sedekah Laut? Bagaimana media online membentuk fakta dan opini publik di masyarakat tentang konflik Sedekah Laut di Panti Baru?

\section{METODE}

Untuk menjawab data penelitian ini, penulis melakukan kerja analisis isi (content analysis) kualitataif. Analisis isi kualitatif merupakan metode yang digunakan untuk memahami pesan simbolik dari suatu wacana atau simbol teks (Krippendorff, 1980). Di penelitian ini pesan-pesan simbolik adalah teks-teks berita yang diperoduksi oleh media online News.Detik.com, Kompas.com, Tribunjogja.com, Jateng.tribunnews.com, Alif.id, Kumparan.com, Geotimes.com, Benarnews.org, dan Republika.co.id. tentang konflik berita Sedekah Laut di Pantai Baru. Pesan simbolik tersebut berupa topik, ide-ide pokok suatu teks berita sebagai isi utama dan konteks gagasan isi laten (Badara, 2012; Mayring, 2003).

Untuk mengupas pesan-pesan simbolik tersebut, penulis melakukan pendekatan analisis kritis, yaitu memusatkan perhatian pada pembongkaran 
aspek-aspek yang terlihat dan yang tersembunyi dibalik peristiwa yang tampak (virtual reality) guna dilakukannya kritik dan perubahan (critique and transformation) terhadap struktur sosial masyarakat (Badara, 2012). Kemudian, penulis akan mendiskusikan temuan ini dengan hasil penelitian-penitian sebelumnya yang dianggap relevan dengan penelitian ini. Penulis akan membahas artikel ini ke dalam lima bagian. Pertama, historis, makna dan tradisi Sedekah Laut. Kedua, kearifan nilainilai lokal dalam tradisi Sedekah Laut. Ketiga, respon masyarakat tentang Sedekah Laut. Keempat, konflik Sedekah Laut di Pantai Baru dan yang terakhir, kelima resolusi konflik Sedekah Laut di Pantai Baru. Penelitian ini dilakukan pada tanggal 24 Desember 2018 sampai tanggal 08 Januari 2019.

\section{HASIL DAN PEMBAHASAN}

\section{Histories, Makna, dan Tradisi Sedekah Laut}

Sebelum Islam masuk ke pulau Jawa, mayoritas masyarakat Jawa memiliki kepercayaan Hindu dan Budha (Simanjuntak, Surawati dan Sukirno 2019). Kepercayaan tersebut bertumpu pada dinamisme benda-benda yang memiliki kekuatan supernatural di luar kemapuan manusia. Seperti batu, pohon, bangunan, gunung dan lain sebagainya. Mereka sangat meyakini adanya kekuatan di dalam bendabenda tersebut. Tidak jarang masyarakat Jawa, khususnya di Yogyakarta mempercayai adanya kekuatan di luar nalar berfikir manusia. Sekarang masih banyak kita temukan kepercayaan dinamisme di Yogyakarta. Di desa-desa Jogjakarta kepercayaan seperti ini masih banyak kita temukan. Misalnya di daerah Kaliadem, Pakem, dan Sawangan yang berdekatan dengan Gunung Merapi. Mereka sangat berpegang teguh pada tradisi yang diwariskan oleh nenek moyang mereka (observasi di tiga desa pinggiran Gunung Merapi, 25/12/2018).

Saat Islam masuk ke pulau Jawa, masyarakat Jawa masih tetap memegang teguh tradisi budaya mereka. Kendati demikian, tradisi ini tidak dilarang. Kehadiran Islam di Jawa tidak lantas menghapus tradisi budaya Jawa. Justru kehadiran budaya lokal dapat memperkuat penyebaran agama Islam di Jawa. Pada situasi seperti ini budaya lokal masih menjadi pijakan di dalam masyarakat Jawa dalam ritual-ritual keagamaan sampai saat ini. Dalam posisi seperti ini, maka nilai-nilai budaya dan ajaran Islam menyatu dalam satu sinergi, yang kemudian dalam teorinya kita sebut sebagai akulturasi budaya.

Akulturasi budaya merupakan perpaduan anarbudaya dari suatu budaya ke budaya lain atau budaya yang berbeda, yang kemudian melebur menjadi satu menghasilkan formulasi budaya baru (Koenjaraningrat, 2002; Asharuddin, 2017). Merujuk pada denfenisi di atas, tradisi-tradisi Jawa seperti Sedekah Laut merupakan salah satu hasil dari akulturasi budaya. Yaitu perpaduan antara nilai-nilai lokal masyarakat Jawa pesisir dengan nilai-nilai Islam Simanjuntak, Surawati dan Sukirno (2019). Ramadani (2018) mengatakan bahwa lahirnya tradisi Sedekah Laut sebagai salah satu bentuk keragaman budaya Indonesia.

Secara umum, kelahiran tradisi Sedekah Laut tidak terlepas dari jalur perdagangan strategis masyarakat pesisir. Dulu bagi masyakarat Jawa pesisir, laut dijadikan sebagai area penting dalam memobilisasi aktivitas ekonomi. Jalur laut menjadi pusat mobilisasi perdagangan ekonomi. Semua aktivitas perdagangan ekonomi bertumpu pada jalur laut. Di samping itu, penghasilan ekonomi masyarakat pesisir diperoleh dari melaut. Aktivitas ini oleh masyarakat pesisir secara terus-menerus dilakukan dan pada akhirnya terbentuklah tradisi Sedekah Laut. Bagi masyarakat setempat, tradisi ini sangat penting. Karena tradisi ini menjadi simbol suci mistisme dan teologis. Tradiis ini dihubungkan dengan adanya roh-roh, makhluk halus dan dewa-dewa yang diyakini sebagai penghuni laut (Abduhrohman, 2015). Kepercayaan ini yang kemudian diterjemahkan dalam bentuk ritual upacara Sedekah laut (Khadaf, 2012; Suryanti, 2017).

Menurut Endra (2013) dan Simanjuntak, Surawati dan Sukirno (2019) secara mendalam tradisi Sedekah Laut mempunyai fungsi yang lebih luas di luar dari konteks mitologi dan ritualistik. Sedekah Laut menjadi ajang persaudaraan, kemudian edukasi budaya, hiburan, informasi dan perduli lingkungan. Menurut Miftah Maulana salah seorang pendakwah Yogyakarta mengatakan:

"ritual ini (Sedekah Laut) adalah nguri-nguri budaya dan tidak masalah. Apabila dalam prakteknya, Sedekah Laut tidak sesuai dengan ajaran agama, maka akan diluruskan. Namun, sangat disayangkan tindakan anarkis yang 
dilakukan seperti ini tidak dibenarkan. Karena masih ada cara-cara yang lebih baik dan bijak untuk menyelesaikan masalah, seperti duduk bersama berdiskusi dalam menyelesaian masalah ini" (detik.com 26/12/2018).

Hal ini sejalan dengan pendapat Endraswara (2005) yang mengatakan bahwa tidak seharusnya tradisi ini menjadi area perselisihan di masyarakat. Menurut dia, kehadiran tradisi ini sebagai bentuk rasa syukur kepada tuhan. Hal ini sejalan dengan Purwahida, Bakhtiar dan Nugrahani. (2008), dan Endraswara dan Ramadhani (2018) yang mengatakan bahwa Sedekah Laut merupakan tradisi ajang pelestarian budaya, dan sekaligus bentuk rasa syukur masyarakat setempat kepada tuhan yang telah memberikan keselamatan. Sejalan dengan pendapat sarjana di atas, Rinta selaku informen media Tribunjogja mengatakan: "budaya Sedekah Laut di Yogyakarta merupakan sarana ucapan bentuk rasa syukur masyarakat kepada tuhan" (Tribunjogja.com/ 25/12/2018).

\section{Kearifan Nilai-Nilai Lokal dalam Tradisi Sedekah Laut}

Tabel 1 menjelaskan tentang nilainilai kearifan lokal tradisi Sedekah Laut.

Tabel 1. Daftar berita tentang kearifan nilai-nilai lokal Sedekah Laut

\begin{tabular}{|c|c|c|c|}
\hline No & Judul Berita & Nama Media & Edisi \\
\hline 1 & $\begin{array}{l}\text { Melihat arti tradisi Sedkeah Laut, bentuk rasa syukur } \\
\text { dalam kacamata budaya }\end{array}$ & News.detik.com & 15 Oktok \\
\hline 2 & $\begin{array}{l}\text { Sedekah Laut dalam pandangan budaya dan agama } \\
\text { Makna Sedekah Laut bagi nelayan di Pantai Baru, } \\
\text { Bantul }\end{array}$ & Alif.id & 15 Oktober 2018 \\
\hline 3 & $\begin{array}{l}\text { Pakar budaya UIN Semarang; Isinya doa dan } \\
\text { pengajian } \\
\text { Sedekah Laut, bukti rasa syukur masyarakat pesisir }\end{array}$ & News.detik.com & 16 Oktober 2018 \\
\hline & pada Yang Kuasa & Kun & 16 \\
\hline 5 & $\begin{array}{l}\text { Sedekah Laut dan moralitas adatBudaya Sedekah } \\
\text { Laut dalam tiniauan hadis }\end{array}$ & $\begin{array}{l}\text { Geotimes.co.id } \\
\text { Alif.id }\end{array}$ & $\begin{array}{l}14 \text { Oktober } 2018 \\
22 \text { Oktober } 2018\end{array}$ \\
\hline
\end{tabular}

Keenam judul berita pada Tabel 1 menjelaskan tentang kearifan nilai-nilai lokal tradisi Sedekah Laut. pertama, Sedekah Laut diartikan sebagai nilai-nilai lokal yang harus dijunjung tinggi. Sebagai orang Jawa, nilai lokal seperti ini terus dihormati. Sudah sejak lama masyarakat Jawa menyakini bahwa tradisi Sedekah Laut banyak memberikan manfaat. Seperti mengajarkan tentang pengorbanan, ketulusan, makna hidup, mengasihi dan solidaritas sosial (News.detik.com/ 26/12/2019). Kedua Sedekah Laut mengajarkan kepada manusia untuk selalu rendah hati, mengasihi, menyayangi, dan mensyukuri nikmat tuhan (News.detik.com; Kumparan.com; Geotimes.co.id/ 25/12/2019). Ketiga menjaga kelestarian alam. Cara ini sebagai bentuk dari keperdulian masyarakat terhadap lingkungan (Alif.or.id/ 27/12/2019). Keempat tentang identitas, harkat, dan martabat suku dan bangsa. Kelima membuang sifat sial dan buruk, dan yang terakhir, keenam menanamkan nilai edukasi, wisata serta hiburan (Alif.or.id; Kumparan.com; News.detik.com/ 26-27/12/2019).

Sedangkan secara luas nilai-nilai terkandung dalam tradisi ini adalah sebagai berikut: 1). Secara sosiologi pringatan tradisi
Sedekah Laut untuk memupuk hubungan sosial masyarakat Pantai Baru. Pelaksanaan ritual ini hendaknya dapat terciptanya suatu hubungan yang baik, kebersamaan dan kekompakan antar warga masyarakat Pantai Baru. Kemudian, meningkatkan hubungan sosial di tengah masyarakat modern yang semakin individualis. Selain itu, tradisi ini memberikan makna yang mendalam yang tidak dapat diterjemahkan dengan kata-kata. 2). Nilai teologis, sikap penyerahan diri kepada penguasa alam sebagai kewajiban seorang petani. Sikap ini secara turun temurun melekat di dalam tradisi masyarakat Jawa. 3). Nilai ekonomis. Adanya Sedekah Laut ini membuat perekonomian masyarakat setempat terangkat. Karena, tradisi ini menjadi destinasi objek wisata. Banyak dari berbagai masyarakat luar berdatangan menyakdsikan tradisi ini. Dengan adanya tradisi ini dapat meningkatkan perekonomian masyarkat setempat. 4). Nilai ekologis, nilai ini menjadi gerakan perduli lingkungan masyarakat. 5). Nilai hiburan bagi masyarakat pesisir sangat penting keberadaanya. Padatnya aktivitas melaut membuat masyarakat pesisir tidak punya waktu untuk menghibur diri. Maka dengan 
tradisi ini bisa memberikan hiburan bagi masyarakat Pantai Baru.

Menurut Berger manusia akan selalu menciptakan makna simbol-simbol suci sebagi pengikat keyakinan manusia. Dia mencontohkan Slametan dan Wilujengan. Dalam tradisi Jawa Slametan dan Wilujengan dimaknai sebagai simbol penghayatan, rasa yukur dan pujian kepada tuhan. Sejalang dengan Berger, Sedekah Laut tidak hanya sebatas ritual, namun juga sebagai bentuk rasa syukur manusia kepada tuhan atas rizki yang telah diberikanNya (Alif.id/27/12/2018). Ramadhani (2018) dan Purwahida, Yunika dan Nugraheni juga mengatakan hal yang sama, menurut mereka Sedekah Laut merupakan ungkapan rasa syukur masyarakat pesisir kepada tuhan Yang Maha Kuasa atas nikmat yang diberikannya. Hal ini sejalan dengan pendapat Simanjuntak, Sarawati dan Sukirno (2019) yang mengatakan Sedekah Laut merupakan wujud implementasi rasa syukur masarakat setempat kepda Tuhan yang maha kuasa. Kemudian (Abdurrahman, 2015) menambahkan Sedekah Laut harapan masyarakat kepada tuhan untuk mendapatkan, kebaikan dan keberkahan atau nilai tambah untuk rizki mereka.

\section{Respon Masyarakat Tentang Makna Sedekah Laut}

Berbagai perusakan tradisi sedekah laut menuai polemik di tengah-tengah masyarkat Pantai Baru. Konflik ini dipicu dari sekelompok masyarakat yang mengharamkan tradisi Sedekah Laut. Sebelumnya, pelaksanaan tradisi ini tidak menimbulkan permasalahan di tengah masyarakat. Kehadirannya justru menjadi ajang silaturahmi, sarana hiburan, edukasi dan objek wisata. Namun, di bulan November 2018 ini pelaksanaan tradisi Sedekah Laut menuai pro-kontra. Ada yang mengatakan tradisi ini bertentangan dengan nilai-nilai Islam (syirik), namun ada juga yang mengatakan tradisi ini hanyalah sebatas tradisi yang tidak sampai pada bentuk-bentuk kesyirikan (Kompas.com; Detik.com; Tribunjogja.com; Kureta.com; Nahimunkar.org 07/01/2019). Tapi curahan rasa syukur mereka kepada tuhan Yang Maha Esa.

Menurut kelompok yang mengharamkan Sedekah Laut, tindakan ini sangat menyimpang dari nilai-nilai Islam. Sementara bagi masyarakat setempat, tradisi Sedekah Laut tidak dianggap menyimpang. Bagi mereka perayaan ini tidak membuat mereka keluar dari Islam. Selain itu, mereka berkewajiban untuk menjaga tradisi ini yang sudah turun temurun agar tidak tergerus oleh perkembangan zaman. Dari perbedaan kedua pandangan tersebut menimbulkan perselisihan dan berbagai respon di tengah masyarakat setempat. Selengkapnya penulis jelaskan hasil analisis penulis tentang respon masyarakat makna Sedekah Laut seperti terlihat pada Tabel 2.

Tabel 2. Respon masyarakat tentang pemberitaan konflik Sedekah Laut

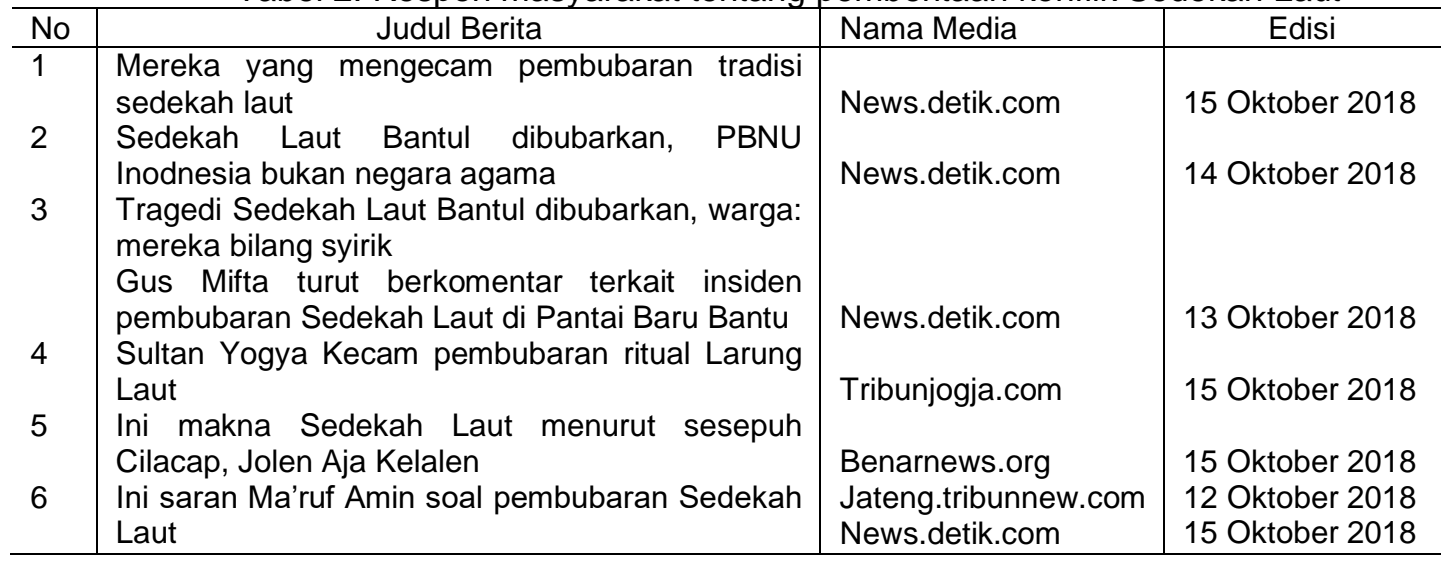

Berdasarkan judul pemberitaan pada Tabel 2, respon masyarakat pada pemberitaan Sedekah Laut sangat beragam. Dari mulai masyarakat umum, tokoh masyarakat dan agama, bupati sampai gubernur. Hampir semua respon di atas mendukung tradisi Sedekah Laut. Mereka sangat kecewa dengan sikap yang dilakukan oleh sekelompok orang yang merusak tradisi Sedekah Laut. Perusakan ini menimbulkan kegaduhan dan kerugian materil. Penjelasan lebih lengkapnya sebagai berikut.

Pertama datang dari kalangan tokoh agama dan tokoh masyarakat. Seperti tokoh Nahdatul Ulama (NU) K.H Maruf Amin, Gus 
Mifta, Helmy Faisal Zaini, Basuki dan Raharja. Mereka mengatakan bahwa Sedekah Laut tidak bertentangan dengan nilai-nilai agama. Justru menurut mereka kehadiran budaya dapat memperkuat agama di masyarakat. Karena Islam yang dikenal di Indonesia adalah Islam yang toleran, menyatu dengan budaya Jawa. Oleh sebab itu, agama dan budaya tidak dapat dipisahkan. Mayarakat akan semakin religius ketika Islam dan budaya dipraktekkan. Contohnya tradisi Kenduri, Yasinan, Gerebekan dan masih banyak lainnya (News.detik.com/01/01/2019).

Kedua pernyataan datang dari Sri Sultan Hamangkubuwono X. Ketiga dari kalangan akademik. Keempat dari kalangan masyarakat, dan yang kelima datang dari masyarakat nelayan. Sikap mereka semua tidak mempermasalahkan tradisi Sedekah Laut. Mereka menilai bahwa Sedekah Laut tidak bertentangan dengan agama. Letak haram dan tidak haram hanya dikembalikan kepribadi orang masing-masing, bagaimana memahami Sedekah Laut (News.detik.com; Tribunjogja.com; Jantengtribunnew.com; Benarnees.org/ 03/01/2019). Nilai-nila itu yang seharusnya diambil, bukan melarangnya atau sampai mengharamkan (News.detik.com/ 03/01/2019).

Bupati Bantul menambahkan "seharusnya tindakan perusakan ini tidak pelu terjadi. Jika terjadi perselisihan di antara masyarakat, seharusnya dilakukan mediasi. Kedua pihak harus mencari jalan keluar masalah" (News.detik.com/ 03/01/2019). Sedangkan kepolisian mengatakan kasus ini masuk dalam tindakan pelanggaran hukum. Kasus ini akan terus diawasi sampai selesai. Perusakan Sedekah Laut merupakan salah satu tindakan yang harus dipidanakan.

Dari mulai pihak kepolisian, akademisisi, budayawan, pejabat daerah, gubernur, bupati, tokoh agama sampai masyarakat biasa, semuanya menolak perusakan tradisi Sedekah Laut. Agar tidak terjadinya perselesihan kembali di tengah masyarakat, mereka menuntut proses penyelesaian secara hukum (News.detik.com/02/01/2019).

Menurut Arif Sujito selaku dosen Sosiologi Universitas Gadjah Mada mengatakan pembubaran tradisi Sedekah Laut terjadi karena adanya perbedaan interpretasi budaya antar kelompok. Sebagian kelompok menilai perayaan tersebut hanya sebatas tradisi yang tidak sampai pada kesesatan, namun ada juga kelompok lain yang penafsiran berbeda
(News.detik.com 07/01/2019). Lebih lanjut, Sujito mengatakan: "tradisi Sedekah Laut menjadi bagian dari sejarah warga pesisir Pantai Baru". Sujito menilai:

"apabila adanya intrepretasi makna yang berbeda terhadap praktek budaya Sedekah Laut jangan sampai berlaku sewenang-wenang. Karena ini merupakan keyakinan merka dalam mengekspresikan perayaan kearifan lokal. Sebagai negara yang demokrasi dan melindungi hak-hak setiap warga negaranya, sudah sepatutnya perbedaan menjadi keniscayaan yang dapat diterima" (News.detik.com 07/01/2019).

Terkait tentang pendapat Sujuto di atas, tokoh agama NU Marif Amin selaku mantan Rais Aam PBNU menilai bahwa konflik ini tidak seharusnya terjadi. Masyarakat seharusnya dapat bersikap lebih dewasa menghadapi perbedaan. la menambahkan, organisasi NU akan segara menyelesaikan persoalan tersebut, agar peristiwa ini tidak berlarut-larut menjadi masalah di tengah masyarakat. Pembahasan konflik ini akan dibahas dalam forum Bahtsul Masail di pengurusan Wilayah (PW) NU Daerah Istimewa Yogyakarta (DIY) (Nahimungkar.org 08/01/2019).

Sedangkan, Sekjen Pengurus NU Helmy Faisal Zaini mengatakan bahwa seharusnya perusakan tersebut tidak dilakukan. Karena negara Indonesia bukan negara agama, akan tetapi negara yang beragama. Setiap warga masyarakat berhak untuk mengekspresikan apa yang telah diyakininya. Kemudian Helmy mengajak kepada seluruh lapisan masyarkat untuk selalu menghormati ragam budaya bangsa Indonesia yang majemuk. Tidak semenamena main hakim sendiri. Soal keyakinan agama masing-masing bagaimana kita menguatkan internal masing-masing, tapi tidak seharusnya melakukan perusakan, karena negara Indoensia adalag negara hukum yang ada di undang-undang (news.detik.com 08/01/2019).

Dari beberbagai respon tersebut, dalam tabel 3 berita di atas menunjukan bahwa kontruksi media online pada berita tersebut ditemukan pecampuran fakta dan opini. Opini pada berita tabel 3 dianggap tidak menyesatkan pembaca, justru membuat masyarakat semakin waspada dan lebih berhati-hati. Kemudian adanya pemberian sangsi sosial kepada pelaku perusak Sedekah Laut atas kesewenangwenangnya. Opini yang positif ini membuat 
masyarakat semakin meningkatkan kewaspadaannya bila ada kelompokelompok orang yang merusak acara tradisi Sedekah Laut.

Sementara, posisi media lebih berpihak pada korban, masyarakat Pantai Baru. Hal ini berdasarkan komentar para narasumber dalam berita tersebut. Seperti mengancam, Mendukung Sedekah Laut, tidak bertentangan dengan nilai-nilai Islam dan lainnya. Dalam hal seperti ini, media memainkan peranannya sebagai tiga unsur penting dalam konseptual media. Di antaranya medan wacana (field of discouse), pelita wacana (tenor of discourse), dan Sarana wacana (mode of discourse) (Syas, 2015).

Medan wacana (field of discouse) sebagai gambaran realitas sosil yang terjadi di lapangan. Media sosial mengkontruksikan realitas sosial tentang pemberitaan konflik budaya Sedekah Laut di Pantai Baru. Media menciptakan ruang opini ke publik untuk mempengaruhi masyarakat. Selanjutnya pelita wacana (tenor of discourse) adalah orang-orang yang keterlibatan dalam pembuatan berita. Dalam hal ini adalah para wartawan. Wartawan sebagai pihak yang terlibat dalam menyusun berita Sedekah Laut. Kemudian, sarana wacana (mode of discourse) sebagai penggunaan bahasa. Prihal penggunaan bahasa oleh media online berpengaruh pada sikap khalayak. Pada akhirnya, khalayak akan menyetujui segala berita yang disamaikan oleh media (Mulharneeti Syas, 2015).

\section{Konflik Sedekah Laut Pantai Baru, Ngentak, Bantul-Yogyakarta \\ Pada bulan Oktober 2018 lalu,} perayaan tradisi Laut di Pantai Baru mendapat kecaman dari sekelompok orang yang tidak dikenal. Kecaman ini berujung pada tindakan perusakan properti Sedekah Laut yang kemudian menimbulkan konflik berujung pada jalur hukum. Konflik ini disebabkan oleh perbedaan pandangan tentang hukum Sedekah Laut, Pada tabel 4 terdapat lima berita dari tiga media online yang berbeda. Media tersebut menyajikan konten berita "konflik" Sedekah Laut di Pantai Baru. Ketiga media online itu menyajikan peristiwa penyebab terjadinya konflik. Selengkapnya penulis hadirkan berita tersebut seperti terlihat pada Tabel 3 .

Tabel 3. Daftar pemberitaan konflik sedekah laut Pantai Baru

\begin{tabular}{|c|c|c|c|}
\hline No & Judul Berita & Nama Media & Edisi \\
\hline 1 & $\begin{array}{l}\text { Polisi periksa } 9 \text { saksi kasus perusakan properti } \\
\text { Sedekah Laut }\end{array}$ & Kompas.com & 15 Oktober 2018 \\
\hline 2 & $\begin{array}{l}4 \text { fakta perusakan Sedekah Laut di Bantul, } 9 \text { orang } \\
\text { diperiksa hingga makna Sedekah } \\
\text { Sekelompok orang bubarkan perisapan tradisi }\end{array}$ & Kompas.com & 15 Oktober 2018 \\
\hline 4 & $\begin{array}{l}\text { Sedekah Laut di Bantul } \\
\text { Pembubaran Sedekah Laut, NU: kekerasan bisa }\end{array}$ & News.detik.com & 13 Oktober 2018 \\
\hline 5 & $\begin{array}{l}\text { pancing disentegrasi } \\
\text { Pengerusakan properti Sedekah Laut masuk ranah } \\
\text { hukum: Wabup }\end{array}$ & $\begin{array}{l}\text { News.detik.com } \\
\text { Republika.co.id }\end{array}$ & $\begin{array}{l}13 \text { Oktober } 2018 \\
20 \text { Oktober } 2018\end{array}$ \\
\hline
\end{tabular}

Pemberitaan padaTabel 3 menjelaskan tentang pengakuan para tersangka yang terlibat dalam perusakan Sedekah Laut. Ada sembilan tersangka yang ditetapkan oleh pihak kepolisian yang terlibat dalam perusakan Sedekah Laut. Kemudian, Tabel 3 juga menjelaskan tentang pengakuan para saksi-saksi yang melihat perusakan properti Sedekah Laut. Para saksi mengatakan, pada saat malam harinya sebelum acara Sedekah Laut dilakukan, sekelompok orang yang tidak dikenal mendatangi tempat acara tersebut. Kemudian sekelompok tersebut merusak properti Sedekah Laut. Mereka membanting meja, kursi, mengobrak-abrik tenda, membuang Labuhan, Pangkur dan Gambyong. Hanya tersisa sebuah Reog yang tidak dirusak. Adapun ciri-ciri mereka menggunakan mobil, memakai gamis, menggunakan cadar dan berteriak Allahhu Akbar. (kutipan News.detik.com/ 07/01/2019).

Selanjutnya, seseorang dari kelompok mereka memasang sepanduk yang bertulisan "kami menolak semua kesyirikan berbalut budaya, Sedekah Laut atau selainnya." Pesan sepanduk tersebut sebagai bentuk perlawanan tradisi Sedekah Laut. Bagi mereka Sedekah Laut dianggap mengandung paraktik-praktik kesyirikan dan kemusyrikan (News.detik.com 07/01/2019).

Pemahaman ini sangat berbeda dengan pandangan masyarakat setempat. Masyarakat Pantai Baru beranggapan bahwa tradisi Sedekah Laut tidak mengajarakan tentang nilai-nilai kesyirikan. Mereka hanya ingin melestarikan tradisi lokal yang secara turun temurun diperingati. Dari kedua makna kontras ini yang kemudian menimbulkan konflik sosial dan 
berakhir pada konflik budaya (Kompas.com 03/01/2019). Menurut Sulaeman (2010) konflik sosial sebagai keinginan dari masing-masing partisipan untuk saling menjatuhkan, dari menjaga kelangsungan daya tahan masingmasing, atau dengan kata lain mereka mengklaim dirinya sebagai kelompok yang paling benar.

Pada Tabel 3 berita keempat dan kelima media, Detik.com dan Kompas.com menjelaskan tentang Sedekah Laut berpotensi memecahbelah masyarakat. Sikap intoleransi kelompok fundamentalis menimbulkan ketegangan di tengah masyarakat. Masyarakat merasa terpukul dengan tindakan mereka. Fajar Abdul Basri mengatakan sebagai negara yang kaya dengan tradisi dan budaya, sudah seharusnya masyarakat saling menghargai. Apabila tidak sejalan dengan tradisi ini, buka berarti semena-mena membubarkan tradisi ini. Niat yang salah terkadang akan membuat masalah baru. Jika sudah konflik, maka harus berurusan dengan hukum. (News.detik.com 07/01/2019).

Dalam kajian sosiologi, konflik diartikan sebagai bentuk pertentangan antara individuindividu atau kelompok-kelompok satu dengan yang lainnya di dalam masyarakat. perbedaan pemahaman ini wujutnya bisa melibatkan dua orang atau lebih dalam gerakan sosial, bisa dalam bentuk kepentingan kelompok, kelas, gender, organiasi, partai politik, etnis, rasa, budaya, atau agama (Jary dalam Umatin, 2017; Simanjuntak, Sarawati, dan Sukirno, 2019). Selain itu konflik dapat terjadi karena teradinya relasi yang tidak baik antara 'vertikal', yang kemudian merambat ke masalah horozontal. Konflik seperti ini sering ditemukan dalam bentuk konflik antar etnis dan antar agama (Mutiara, 2016).

Sementara menurut Ahmad (1991) konflik sosial tidak selamanya terjadi dalam bentuk gesekan fisik antara individu maupun kelompok masyarakat. Tetapi terjadinya taktik untuk melemahkan pihak lawan dengan cara menghiraukan norma dan nilai yang berlaku dalam masyarakat. Hal ini sejalan dengan kasus yang terjadi pada masyarakat Ngentak, Pantai Baru. Kelompok perusak Sedeah Laut tidak melakukan penyerangan secara fisik kepada masyarakat. Mereka hanya merusak properti Sedekah Laut, dan mendirikan sepanduk yang bertuliskan "kami menolak semua kesyirikan berbalut budaya, sedekah laut atau selainnya" sebagai bentuk protes terhadap perayaan ritual Sedekah Laut ((News.detik.com 07/01/2019). Protes ini diartikan sebagai bentuk perlawanan terhadap norma dan nilai-nilai masyarakat.
Salah seorang sosiologi bernama Lewis Coser menyatakan konflik adalah pertentangan atau perjuangan bersifat langsung dan disadari antar individu atau kelompok untuk memperoleh pengakuat status, kekuasaan, kepatuhan, dan sumber daya. Pada saat yang sama masingmasing pihak saling berusahan melenyapkan pengaruh dari pihak lain (Coser 1957).

Nothingham (1997) menyebutkan bahwa seharusnya tingkah laku masyarakat ditata dan dipolakan sesuai dengan prinsip yang relatif diterima dan disepakti bersama, sehingga nilai yang ada dapat diintergrasikan dalam suatu tatanan yang berarti dan mengarah pada sebuah tatanan masyarakat dapat bersatu. Dari uraian pendapat Coser, konflik budaya Sedekah Laut yang terjadi di Pantai baru dapat ditekan melalui cara perundingan, dipolakan berdasarkan klasifikasi poin-poin yang kemudian disepakati bersama, sehingga perbedaan pandangan di antara mereka dapat terselesaikan dengan baik.

Dalam teori konflik sosial, ada empat pendapat yang menyebabkan terjadinya konflik sosial di masyarakat. Pertama, setiap komunitas masyarakat akan mengalami perubahan sosial. Kedua, setiap waktu di masyarakat selalu adanya konflik sosial yang tidak dapat dihindari. Ketiga, setiap elemen masyarakat menyumbangkan perubahan sosial. Keempat, setiap masyarakat didasarkan atas tekanan para anggota membuka ruang terjadinya konflik (Johnson, 1986). Pendapat lain tentang teori konflik sosial juga dikemukakan oleh Retnowati (2018) yang mengatakan konflik sosial yang terjadi pada masyarakat disebabkan masalah perbedaan ideologi, memahai arti nilai-nilai budaya. Kemudian terjadinya kecurigaan atas kepentingan kelompok, ketidaksenangan kelompok, cemburu yang disertai dengan stereoytpe pada individu, dan berbedaan pandangan terhadap kelompoknya. Konfilik sosial yang dikemukakan oleh kedua sarjana tersebut ketika menganalisis penyebab terjadinya konflik tradisi Sedekah Laut di Pantai Baru disebabkan oleh perbedaan ideologi. Kemudian berdampak pada aspek konflik lainnya.

Menurut Weber subtanis terdapat dalam kerangka hubungan sosial yang bersifat intensional dan adanya perbedaan orientasi, yaitu untuk tidak saling memberi makna yang sama sebagai pertarungan 'laten' memperoleh kedudukan dan status sosial. Menurut Aron dalam (Sulaeman, 2010). Pandangan Weber menganggap konflik sebagai proses intraksi sosial atas keinginannya partisipan yang saling menjatuhkan egonya masing-masing.

Lebih lanjut, Weber menambahkan mekanisme produksi emosi merupakan alat 
utama digunakan dalam konflik. "Ritual emosi" digunakan sebagai dominasi suatu kelompok. Kesadaran mereka membawa aliansi kelompok (solidaritas sosial) untuk menentang kelompok lain dan meruntuhkan hirarki dari status prestasi. Weber menyusun semua aspek dominasi melalui manipulasi solidaritas emosi, sehingga meliputi banyak bentuk stratifikasi komunitas berdasarkan budaya (Collins dalam Sulaeman, 2010).

Berdasarkan teori di atas, dapat dipahami bahwa konflik di Pantai Baru sebagai bentuk dari ketidakpuasan sekelompok Islam tertentu (fundamentalis) terhadap praktik ritual Sedekah Laut. Kelompok fundamentalis mengganggap tradisi tersebut adalah tindakan yang dilarang oleh ajaran Islam, yang mengandung nilai-nilai kemusrikan dan kesirikan. Berpijak dari pemahaman ini, mereka mengecam segala bentuk praktik-praktik tradisi Sedekah Laut yang dianggap menimbulkan kemusyrikan. Mereka berharap dengan merusak properti tersebut, tradisi Sedekah Laut ini tidak akan diulang kembali. Namun, dalam kaca mata masyarakat Pantai Baru tindakan perusakan properti Sedekah Laut justru akan menimbulkan perselisihan. Ketika terjadinya konflik seperti ini, di antara kedua belah pihak, manipulasi solidaritas emosi terjadi. Artinya, pelaku yang melakukan perusakan properti Sedekah Laut tidak lagi berfikir secara rasional. Akal yang sehat tegantikan oleh lautan emosi yang tidak rasional yang berdampak pada pelanggaran hukum. Hukum sosial yang sudah tertanam secara mengakar di masyarakat jika dilanggar akan berdampak pada reaksi kemarahan warga. Oleh karena itu, budaya yang sudah tertanam secara kuat di masyarakat jika diusik akan meimbulkan kesinsitifan publik.

Melihat dari gejala konflik ini, ada dua hal mendasar yang membuat kedua belah pihak konflik, yaitu tentang pemahaman dan. Muslim fundamentalis menganggap Sedekah Laut tidak sejalan dengan ajaran agama (syirik dan haram). Sedangkan masyarakat setempat menganggap Sedekah Laut tidak bertentangan dengan agama. Kedua pendapat yang berbeda ini yang disebut sebagai social resistance yaitu titik temu yang tidak ada solusi penyelesaian masalah. Muslim fundamentalis ialah gerakan Islam yang berideologi garis keras. Keras tersebut dilandaskan pada kehati-hatianya dalam memahami sumber Qur'an dan Hadis. Semakimal mungkin kelompok fundamentalis Hal ini berbeda dengan kelompok Islam moderat. Islam moderat lebih ramah, 'renggang'. toleran dan tidak mudah mejastifikasi pemahaman yang diyakini oleh orang lain. Islam moderar meletakkan nilai dan budaya lokal sebagai perjuangan dakwah, identitas dan kehormatan bangsa (Umatin 2017).

Dalam banyak kasus yang ada, Islam fundamental sudah sejak lama bersebrangan dengan cara pemahaman Islam moderat, dan masyarakat yang masih memegang budaya monotisme dan Islam abangan. Hal ini disebabkan oleh berpedaan cara memahami hukum dalam memahami Qur'an dan Hadis, sebagai stadar baku dalam menetapkan hukum Islam di masyarakat (Umatin 2017).

\section{Resolusi Konflik Sedekah Laut Pantai Baru, Ngentak, Bantul-Yogyakarta}

Pada Tabel 4 ditemukan penyelesaian konflik Sedekah Laut di laman berita online Detik.com. Detik.com menjelaskan bahwa masyarakat Pantai Baru menarik tuntutan pengerusakan tradisi Sedekah Laut. Pencabutan laporan ini memperlihatkan bahwa masyarakat sudah melupakkan peristiwa itu. Pasa posisi seperti ini proses resolusi konflik terjadi. Konflik di antara mereka terselesaikan. Sembilan saksi yang klaim sebagai pelaku perusak Sedekah Laut dipulangkan.

Dalam pendekatan teori sosial masyarakat Pantai Baru menggunakan pendekatan teori resolusi konflik reduksi trandensental dalam teori the intentionalist pradigm (Morton and Coleman 2006). Masyarakat Pantai Baru menarik diri untuk tidak memperpanjang konflik ini, kesadaran intropeksi ini menghasilkan resolusi konflik teori reduksi trandensental seperti terlihat pada Tabel 4.

Tabel 4. Daftar pemberitaan konflik sedekah laut Pantai Baru

\begin{tabular}{l|l|l|l}
\hline No & \multicolumn{1}{|c|}{ Judul Berita } & Nama Media & \multicolumn{1}{|c}{ Edisi } \\
\hline 1 & $\begin{array}{l}\text { 9 orang yang terciduk terkait pembubaran Sedekah } \\
\text { Laut dipulangkan }\end{array}$ & News.detik.com & 15 Oktober 2018 \\
2 & $\begin{array}{l}\text { Pembubaran terbaru soal kasus pembubaran Sesekah } \\
\text { Laut Bantul }\end{array}$ & News.detik.com & 15 Oktober 2018 \\
\hline
\end{tabular}

Berita pada Tabel 4 memperlihatkan bahwa pelaku perusak properti Sedekah Laut telah dibebaskan. Sebelunya pihak kepolisian telah mempersiapkan berkas pengajuan untuk pemrosesan lebih lanjut. Namun, masyarakat Pantai Baru mencabut tuntutan itu. Masyarakat Pantai Baru tidak ingin kasus ini diteruskan kembali. Kasus ini 
diselesaikan secara kekeluargaan (News.detik.com/ 07/01/2019). Kedua belah pihak sepakat untuk berdamai. Kemudian pihak kepolisian memperingatkan kepada masyarakat pesisir Pantai Baru untuk waspada, berhati-hati dengan segala aksiaksi yang ingin menggagalkan tradisi ini di tahun yang akan datang. Diharapkan peristiwa ini menjadi pelajaran semua masyarakat Jawa untuk tidak melakukan tindakan main hakim sendiri. Masih ada cara-cara lain yang lebih baik dilakukan. Hidup di negara yang besar dengan kemajemukan budaya sudah seharusnya perbedaan disikapi secara bijak (News.detik.com/ 07/01/2019).

Rawis dalam (Menon, 2015) mengatakan tidak akan pernah tercapai keharmonisan hubungan antar warga apabila warga masyarakatnya tidak saling menghormati keyakinan orang lain. Sebagai negara yang menganut sistem demokrasi, sudah semestinya warga negara menghormati, terbuka dengan pandangan orang lain. Orang lain juga berhak menyampaikan ide, pandangan dan alasanalasan berdasarkan apa yang diyakininya.

Nalar publik (public reasion) dalam teori Rawls menempatkan manusia sebagai kekebasan individu dan kesetaraan individu dari diskriminasi dan penindasan (Menon, 2015). Dalam kasus agama, perbedaan keyakinan tentang ide, gagasan dan pandangan sangat sensitif. Maka seringkali agama menjadi sumber konflik. Seharusnya, doktrinisasi agama dalam teks suci harus dilakukan penalaran publik (public reasion) kembali, agar tidak terjadinya perselisihan di masyarakat yang heterogen (Menon, 2015).

Untuk memecahkan sulusi konflik, Hebermas menawarkan dua cara pandang penyelesaian konfliik, yaitu melalui 'ruang publik informal' dan 'ruang publik formal.' Ruang publik informal adalah penyelesaian masalah dalam ruang tertutup. Di ruang tertutup ini, kelompok masyarakat bebas menyampaikan pemikiran kepada kelompok lain untuk mencari solusi jalan keluar. Sedangkan publik formal adalah solusi penyelesaian masalah yang dilakukan dengan menggunakan pendekatan ruang terbuka, di mana kelompok masyarakat harus menyampaikan pandangan yang bersifat umum, tidak boleh bertentangan dengan nilai-nilai umum dan tidak dibenarkan menyerang keyakinan orang lain. Jika kedua cara ini dilakukan maka perbedaan pemahaman dapat dikendalikan dengan baik. Konflik-konflik agama pun dapat diminimalisir secara tepat (Menoh, 2015).

Berbeda dengan Morton and Coleman (2006) penyelesaian konflik dapat dilakukan dengan cara menjauhi sumber konflik. Dalam hal ini, di antara salah satu pihak atau keduan belah pikah menjauhkan diri dari sumber konflik. Dengan sendirinya konflik itu akan terselesaikan. Sedangkan menurut Salamet (2018) penyelesaian konflik agama akan terselesaikan bila kedua belah pihak saling dialog sampai ke partisipan aktif (mengakar) untuk menemukan jalan keluar yang efektif tanpa adanya tindakan kekarasan dan merugikan di antara ke dua belah pihak.

Berdasarkan pemaparan ini dapat dipahami bahwa resolusi konflik dilakukan melalui tiga cara, yaitu pendekatan penalaran publik (public reasion), ruang publik informal dan formal. Masyarakat Pantai Baru melibatkan individu atau kelompok untuk melakukan penyelesaikan konflik Sedekah Laut melalui pendekatan kesadaran intropeksi melalui teori reduksi trandensental. Di samping itu, masyarakat juga melakukan cara-cara pendekatan demokratis dan konstruktif untuk menyelesaikan konflik. Dengan memeberikan kesempatan pada pihakpihak yang berkonflik untuk terlibat dalam memecahkan masalah. Menurut analisis penulis, kesadaran masyarakat Pantai Baru untuk tidak melanjutkan proses tuntutan hukum merupakan resolusi konflik.

\section{SIMPULAN DAN SARAN}

Berdasarkan hasil pemaparan pembahasan di atas, dapat disimpulkan bahwa terjadinya konflik Sedekah Laut di pantai Baru disebabkan oleh adanya perbedaan pemahaman hukum Sedekah Laut. Kelompok yang menolak Sedekah Laut diidentifikasi sebagai kelompok Islam fundamentalis.

Islam findamentalis ialah aliran dari kelompok Islam yang menggunakan pendekatan hukum Islam berdasarkan perspektif teksualitas. Konsep hukum yang dikenal oleh kelompok ini adalah salaf alshalih, yaitu mengikuti jejak keteladanan generasi awal Muslim. Secara eksplisit mereka diri mereka menyebutnya sebagai "Salafi", Islam yang sangat rigid, upaya penurnian tauhid dan praktik keagamaan eksklusif. Berpijak dari sinilah mereka menganggap bahwa praktik Sedekah Laut di Pangtai Baru dianggap kesyirikan, sehingga 
membumat umat Islam menjadi murtad, keluar dari agamanya.

Sedangkan Islam moderat tidak mempersoalkan pelaksanaan Sedekah Laut. Islam moderat tidak menolaknya keberadaan budaya Sedekah Laut. Mereka mendukung segala bentuk pelaksanaan tradisi Sedekah Laut, sama halnya juga dengan masyarakat Jawa secara umum, mendukung pelaksanaan tradisi Sedekah Laut. Islam moderat menilai bahwa tradisi Sedekah Laut penting untuk dilestarikan. Sebab cerminan identitas bangsa, yang menggambarkan tentang toleransi, menghargai dan menjunjung tinggi nilai-nilai budaya lokal sebagaimana hal ini telah dilakukan oleh Wali Songo ketika menyebarkan agama Islam di tanah Jawa.

\section{DAFTAR PUSTAKA}

Abdurrohman, M. 2016. Memahami MaknaMakna Simbolik Pada Upacara Adat Sedekah Laut di Desa Tanjungan Kecamatan Kragan Kabupaten Rembang. Jurnal The Messenger, 7(1), 27-34.

Adha, M. A. 2011. Makna Simbol dalam Upacara Sedekah Laut di Desa Taksin Agung Kecamatan Rembang Kabupaten Rembang Tahun. Skripsi. Solo: Universitas Muhamadiyah Surakarta.

Asturi, P. 2014. Komunikasi Sebagai Sarana Alkuturasi Antar Kaum Urban dengan Masyarakat Lokal di Pasar Segiri Samarinda. IImu Komunikasi, 2(1), 305-320.

Badruzzaman, B. 2016. Eksis Civil Society dalam Melestarikan Budaya Pesisir (Studi Kasus Kelompok Babagan dalam mempertahankan Upacara Sedekah Laut di Kampung Nelayan Padangan Kabupaten Rembang) Jurnal Ilmu Politik, 7(2), 34-52.

Badara, A. 2012. Analisis Wacana: Teori, Metode, dan Penerapannya Pada Wacana Media. Jakarta: Kencana.

Endraswara, S. 2005. Tradisi Lisan Jawa. Yogyakarta: Narasi.

Geertz, Clifford. 2013. Agama Jawa: Abangan, Santri, Priyayi dalam Kebudayaan Jawa. Yogyakarta: Komunitas Bambu.

Hasan, N. 2006. Laskar jihad. No. 40. SEAP Publications.

Johnson, D. P. 1986. Teori Sosiologi Klasik dan Modern. Jakarta: Gramedia.

Krippendorff, K. 1980. Content Analysis, An Introduction to It's Methodologi. London: Sage Publication, 22.
Kusmintayu. 2014. Upacara Tradisi Sedekah Laut di Kabupaten Cilacap (Tinjauan Makna, Kearifan Lokal, dan Relevansinya dengan pembelajaran Bahasa di SMA/SMK).Tesis. Surakarta: Pascasarjana UNES.

Mayring, P. 2003. Qualitatif Content Analiysis. Forum Qualitativ Research. 2. (http.Qualitative-research.net/fqsnexte/2-002/2-00mayring-e-html)

Menoh, G. A. 2015. Agama dalam Ruang Publik: Hubungan antara Agama dan Negara dalam Masyarakat Postsekuler Menurut Jurgen Habermas. Yogyakarta: PT Kanisius.

Morton, D. \& Coleman, P. T. 2006. The Handbook of Conflict Resolution, Theory and Practice. San Fransisco: Jossey-Bass Publisher.

Mutiara, K. E. 2016. Menanamkan Toleransi Multi Agama sebagai Payung Anti Radikalisme: Studi Kasus Komunitas Lintas Agama dan Kepercayaan di Pantura Tali Akrab. Fikrah, 4(2), 293302.

Purwahida, R., Bakhtiar, D. Y., \& Nugrahani, D. 2008. Bahasa Dalam Upacara Larung, Sedekah Laut $\mathrm{Di}$ Laut Bonang, Kecamatan Lasem, Kabupaten Rembang, Jawa Tengah. Pelita-Jurnal Penelitian Mahasiswa UNY 1.

Ramadani, R. G. 2018. Islam dalam Tradisi Sedekah Laut di Desa Karangbenda Kecamatan Adipali Kabupaten Cilacap. Skripsi. Cilacap (ID): IAIN Purwokerto.

Retnowati, P. 2018. ";Agama, Konflik dan Integrasi Sosial Refleksi Kehidupan Beragama di Indonesia: Belajar dari Komunitas Situbondo Membangun Integrasi Pasca Konflik." SANGKéP: Jurnal Kajian Sosial Keagamaan, 1(1), 1-28.

Rosyid, M. 2015. Esai-Esai Toleransi. Yogyakarta: Tim Idea Press.

Ruslan, Idrus. 2014. Religiositas Masyarakat Pesisir: Studi Atas Tradisi "Sedelah Laut" Masyarakat Kelurahan Kangkung Kecamatan Bumi WarasKota Bandar Lampung. AlAdyan: Jurnal Studi Lintas Agama, 9(3), 63-88.

Rustiana, D. \& Hotimah, H. 2017. Alms Earth and Sea as a Manifestation of Multiculturalism of Religion People, dalam Hipoliticus K. Kewuuel, dkk. Seri Studi Kebudayaan 1 Pruralisme, Multikulturalisme, dan Batas-Batas Toleransi. Malang: Program Studi 
Eko Saputra,Iswandi Syahputra,Bono Setyo | Pemberitaan Media Online: Studi Kasus Konflik Budaya "Sedekah Laut" Di Pantai Baru, Ngentak, Bantul, Yogyakarta

Antropologi Fakultas IImu Budaya Universitas Brawijaya. 85-90.

Simanjuntak, D., Retno S., \& Sukirno. 2019. "Hukum Yang "Berperasaan" Dalam Penyelesaian Konflik Antara Budaya Dan Agama: Penolakan Administratif Terhadap Tradisi Sedekah. Governance Journal, 2(3), 499-510.

Salamet, S. 2018. Dialog Umat Beragama: Dari Mobilisasi Ke Partisipasi Aktif Dalam Analisa Keindonesiaan. Empirisma: Jurnal Pemikiran Dan Kebudayaan Islam, 27(1).

Solihin, R. 2015. Studi Tentang Budaya Rokat Tase' di Desa Gebang Kecamatan Bangkalan Kabupaten Bangkalan Jawa Timur. Skripsi. Surabaya: UIN Sunan Ampel.

Sulaeman, M. M. 2010. Dasar-Dasar Kondlik dan Mudel Resolusi Konflik pada Masyarakat Desa Pantura Jabar. Sosiohumaniora, 12 (2).

Suryanti, A. 2017. "Upacara Adat Sedekah Laut di Pantai Cilacap." Sabda: Jurnal Kajian Kebudayaan, 3(2).

Syas, M. 2015. Kontruksi Realitas Pemberitaan tentang Konflik Indonesia-Malaysia di Surat Kabar Media Indonesia. Jurnal IImu Komunikasi, 13(2), 124-134.

Ummatin, K. 2017. Konflik Dan Integrasi Umat Beragama Dalam Budaya Lokal Di Loka Muksa Sri Aji Joyoboyo Menang Pagu Kediri. Penelitian Agama dan Masyarakat, 1(1), 37-51.

Widati, S. 2011. Tradisi Sedekah Laut di Wonokerto Kabupaten Pekalongan: Kajian Perubahan Bentuk dan Fungsi, Jurnal $P P, 1$ (2).

Wildan, A. 2015. Tradisi Sedekah Laut Dalam Etika Ekologi Jawa (di Desa Gempol Sewu Kecamatan RowosariKabupaten Kendal. Skripsi. Semarang: UIN Walisongo Semarang.

\section{Media Online}

Alif.or

Harianjogja.com

Kompas.com

Liputan6.com

Nahimunkar.org

News.detik.com

Nu.or.id

Swaramerdeka.com

Tribunjogja.com 